\title{
Analisis Prosedur Pengeluaran Kas Pada PT Jasa Raharja (Persero) Cabang Sumatera Selatan
}

\author{
Meri Lisma ${ }^{1}$, Oktariansyah ${ }^{2}$ \\ ${ }^{1}$ Akuntansi, FE Universitas PGRI Palembang \\ ${ }^{2}$ Akuntansi, FE Universitas PGRI Palembang, email: rianbro82@univpgri-palembang.ac.id
}

\begin{abstract}
This study aims to determine the cash disbursement procedure for payment of compensation at PT Jasa Raharja (Persero) South Sumatra Branch. The data used in this study are primary data. The data collection techniques used were interviews and documentation. The population taken in this study is the cash disbursement procedure system at PT Jasa Raharja (Persero) South Sumatra Branch while the sample taken in this study is the procedure of payment of compensation at PT Jasa Raharja (Persero) South Sumatra Branch. The data analysis technique used in this study is a qualitative descriptive technique. Based on the results of the research on the procedure for payment of compensation to PT Jasa Raharja it is quite good but there are still many procedures that must be passed. Submission of compensation must be included with the completeness of the files in accordance with the requirements that have been determined and if these requirements are not complete then the application for filing compensation cannot be processed. For PT Jasa Raharaja's cash disbursement procedure, it is good enough, but in its financial department it is still checking BKKProof of Transaction Journals that sometimes BKK-Proof Journal Transaction is not right with the ERP company so the cashier does reprinting.
\end{abstract}

Keywords : Cash Expenditure Procedure, Compensation Payment

\begin{abstract}
ABSTRAK
Penelitian ini bertujuan untuk mengetahui prosedur pengeluran kas terhadap pembayaran santunan pada PT Jasa Raharja (Persero) Cabang Sumatera Selatan. Data yang digunakan dalam penelitian ini adalah data primer. Tehnik pengumpulan data yang digunakan adalah wawancara dan dokumentasi. Populasi yang diambil dalam penelitian ini adalah sistem prosedur pengeluaran kas pada PT Jasa Raharja (Persero) Cabang Sumatera Selatan sedangkan sampel yang diambil dalam penelitian ini adalah prosedur pembayaran santunan pada PT Jasa Raharja (Persero) Cabang Sumatera Selatan. Tehnik analisis data yang digunakan dalam penelitian ini adalah tehnik deskriptif kualitatif. Berdasarkan hasil penelitian pada prosedur pembayaran santunan pada PT Jasa Raharja sudah cukup baik akan tetapi masih banyak prosedur yang harus dilewati. Pengajuan santunan harus disertakan dengan kelengkapan berkas yang sesuai dengan persyaratan-persyaratan yang telah ditentukan dan apabila persyaratan-persyaratan tersebut belum lengkap maka permohonan pengajuan santunan belum bisa diproses. Untuk Prosedur pengeluaran kas PT Jasa Raharaja sudah cukup baik namun pada bagian keuangannya masih melakukan pengecekan BKK-Bukti Jurnal Transaksi yang terkadang BKK-Bukti Jurnal Transaksi belum tepat dengan ERP perusahaan sehingga bagian kasir melakukan pencetakan ulang.
\end{abstract}

Kata Kunci : Prosedur Pengeluaran Kas, Pembayaran Santunan 


\section{A. Latar Belakang}

Manusia sepanjang hidupnya dimana saja dan kapan saja akan senantiasa menghadapi kemungkinan terjadinya peristiwa-peristiwa yang dapat merugikan dirinya. Dengan kata lain manusia akan menghadapi berbagai resiko yang mungkin akan dideritanya yang dapat menimpa dirinya atau harta bendanya.Disisi lain manusia dapat saja berusaha melakukan pencegahan terhadap kemungkinan terjadinya resiko yang tidak diinginkan, akan tetapi dalam kenyataannya resiko itu tidak dapat ditiadakan sama sekali sehingga pada suatu saat tertentu kerugian itu akan dialami oleh manusia. Untuk itu manusia telah melakukan berbagai cara yang dapat ditempuh, salah satu cara yang dilakukan untuk mendapatkan jaminan serta mendapatkan perlindungan dalam menghadapi terjadinya resiko tersebut adalah melalui asuransi. Dengan asuransi orang dapat mengalihkan resikonya kepada pihak lain.

Perusahaan asuransi mempunyai peranan yang sangat penting, baik dari segi peranan sosial maupun ekonomi. Peranan sosial merupakan suatu perusahaan asuransi yang menawarkan jasa perlindungan bagi masyarakat yang membutuhkan jasa asuransi tersebut dengan membayar premi, sedangkan peranan ekonomi dimana perusahaan asuransi berposisi sebagai lembaga keuangan non bank yang menyediakan diri dalam keadaan tertentu untuk menanggung resiko kerugian secara ekonomi.

Perusahaan asuransi memiliki beberapa jenis, dan tersebar di seluruh penjuru Indonesia. Adapun jenis-jenis asuransi yang ada di indonesia antara lain asuransi jiwa, asuransi kecelakaan, asuransi kerugian, asuransi pendidikan dan lain sebagainya. Untuk melaksanakan tugas dan kegiatannya transaksi ekonomi jelas banyak sekali prosedur-prosedur yang akan ditempuh dan semua itu merupakan tanggung jawab bagi pihak yang berkecimpungan dalam dunia perasuransian. Pelaksanaan tugas tersebut dimulai dari penerimaan premi dan pembayaran klaim pada konsumen.

Usaha asuransi yang sehat merupakan salah satu upaya untuk menanggulangi resiko yang dihadapi oleh anggota masyarakat dan sekaligus merupakan salah satu lembaga penghimpun dana masyarakat, sehingga memiliki kedudukan strategis dalam pembangunan dan kehidupan perekonomian dalam upaya memajukan kesejahteraan umum.

Perusahaan-perusahaan asuransi yang ada di Indonesia ini semakin berkembang dengan pesat seiring perkembangan zaman yang semakin maju. Situasi yang terjadi sekarang ini akan mendorong pula adanya persaingan dari perusahaan asuransi swasta yang berlomba-lomba menarik masyarakat untuk membeli jasa asuransi yang ditawarkan. Seiring dengan perkembangan suatu negara yang secara langsung maupun tidak langsung akan mempengaruhi tatanan perekonomian, cara-cara pemasaran, perilaku manusianya serta sistem informasi yang diterapkan.

Jasa Raharja (Persero) sebagai Badan Usaha Milik Negara (BUMN) dana pertanggungan wajib kecelakaan penumpang dan yang bertugas memberikan perlindungan dasar kepada masyarakat melalui dua program, yaitu asuransi kecelakaan penumpang alat angkutan umum yang dilaksanakan berdasarkan undang-undang No. 33 Tahun 1964 tentang dana pertanggungan wajib kecelakaan 
penumpang serta tanggung jawab hukum menurut hukum terhadap pihak ketiga yang dilaksanakan berdasarkan undang-undang No. 34 Tahun 1964 tentang dana kecelakaan lalu lintas jalan. Dalam menghadapi persaingan yang semakin ketat mendorong para manajernya untuk terus menerus memperbaiki pemasarannya, struktur organisasi, serta yang tidak kalah pentingnya adalah sistem akuntansi yang didalamnya terdapat pengeluaran kas, yang terkadang timbul hambatan pada saat pelaksanaan penyelesaian santunan karena administrasi kelengkapan nasabah yang kurang lengkap.

Dengan demikian hal yang menarik untuk di analisa adalah bagaimana prosedur pengeluaran kas yang diterapkan oleh bagian keuangan PT Jasa Raharja (Persero). Yang sebelumnya di teliti olehFebriani (2014) dengan judul Analisis Sistem Dan Prosedur Pengeluaran Kas Terhadap Pembayaran Klaim Pada AJB Bumi Putra 1912 Cabang Cinde Palembang dengan hasil Prosedur pembayaran klaim yang dilakukan perusahaan sudah cukup baik, tetapi dalam pemorosesannya pembayaran klaim masih kurang efektif. Hal ini terjadi karena klaim baru dapat diproses apabila persyaratan atau berkas-berkas yang ada pada pemengang polis sudah lengkap secara keseluruhan. Hal ini biasanya akan memperlambat proses pembayaran klaim.

\section{B. Rumusan Masalah}

Berdasarkan latar belakang masalah yang ada, maka penulis menitik beratkan pada rumusan masalah, yaitu: bagaimana Prosedur Pengeluaran Kas (Pembayaran Santunan) Pada PT Jasa Raharja (Persero) Sumatera Selatan?

\section{Metode Penelitian}

Menurut sugiyono (2013:5) metode penelitian adalah cara ilmiah untuk mendapatkan data yang valid dengan tujuan dapat dikemukakan, dikembangkan, dan dibuktikan, suatu pengetahuan tertentu sehingga pada gilirannya dapat digunakan untuk memahami, memecahkan, dan mengantisipasi masalah dalam bidang bisnis.Dalam ini penulis menggunakan metode deskriftif kualitatif yaitu metode yang menggunakan untuk menganalisa data dengan cara mendiskrisikan atau menggambarkan keaadaan yang sebenarnya berdasarkan apa yang tampak kemudian digunakan dalam menggunakan memecahkan suatu masalah dengan mengumpulkan, menyusun, menganalisis dan menginterprestasikan data sehingga dapat ditarik kesimpulannya.

\section{Populasi dan Sampel \\ 1) Populasi}

Menurut Sugiyono (2013:115) Populasi adalah wilayah generasi yang terdiri atas objek atau subjek yang mempunyai kualitas dan karakteristik tertentu yang ditetapkan oleh peneliti untuk mempelajari dan kemudian ditarik kesimpulannya.Adapun populasi yang diambil dalam penelitian ini adalah sistem prosedur pengeluaran kas pada PT Jasa Raharja (Persero) Cabang Palembang.

\section{2) Sampel}

Menurut sugioyono (2013:116) sampel adalah bagian dari jumlah dan karakteristik yang dimiliki oleh populasi tersebut.Adapun sampel yang diambil dalam 
penelitian ini yaitu prosedur pembayaran Santunan pada PT Jasa Raharja (Persero) Cabang Palembang.

\section{F. Tehnik Pengumpulan Data}

Menurut Sugiyono (2013:193) untuk memenuhi data dan informasi dapat dilakukan dengan beberapa teknik, adapun teknik pengumpulan data yang digunakan yaitu:

\section{a. Observasi}

Menurut Nasution (1988) yang dikutip dari Sugiyono (2013:403) observasi adalah dasar semua ilmu pengetahuan.Para ilmuawan yang hanya dapat bekerja berdasarkan data, yaitu fakta mengenai dunia kenyataan yang diperoleh melalui observasi.Melakukan obsevasi atau pengamatan, dalam hal ini penulis melakukan pengamatan langsung dengan tempat peneliti dan mencatat secara sistematis semua data yang ada hubungannya dengan penulisan skripsi ini.

\section{b. Dokumentasi}

Menurut Sugiyono (2013:422) dokumentasi adalah catatan peristiwa yang sudah berlalu.Dokumen bisa berbentuk tulisan, gambar, atau karya-karya monumental dari seseorang. Data yang digunakan Dalam penelitian ini adalah berupa dokumentasi dari perusahaan yang telah dipublikasikan seperti sejarah perusahaan,strukturorganisasi, dan pembagian tugas dan tanggung jawab.

\section{c. Wawancara}

Menurut Sugiyono (2013:410) wawancara adalah pertemuan dua orang untuk bertukar informasi atau ide melalui tanya jawab, sehingga dapat dikonstruksikan makna dalam suatu topik tertentu. Wawancara tidak dilaksanakan dengan sturtur yang ketat, tapi dengan pertanyaan yang semakin memfokus pada permasalahan sehingga informasi yang terkumpul sangat mendalam.

\section{G. Tehnik Analisis Data}

Menurut Sugiyono(2013:428) Analisis data adalah proses mencari dan menyusun secara sistematis data yang diperoleh dari hasil wawancara, catatan lapangan, dan dokumentasi, dengan cara mengorganisasikan data kedalam kategori, menjabarkan kedalam unit-unit, melakukan sintesa, menyusun kedalam pola, memilih mana yang penting dan yang akan dipelajari, dan membuat kesimpulan sehingga mudah dipahami oleh diri sendiri maupun orang lain. Teknik analisis data yang digunakan dalam penelitian ini adalah teknik deskriptif kualitatif, yaitu menganalisis sistem dan prosedur pengeluaran kas terhadap Santunan PT Jasa Raharja (Persero) Cabang Palembang menggunakan bagan alir (flowchart), terhadap teori yang berhubungan dengan sistem dan prosedur pengeluaran kas dalam akuntansi, kemudian diberikan kesimpulan dan saran yang tepat untuk memperbaiki temuan yang terjadi. 


\section{H. Hasil dan Pembahasan}

Berdasarkan teori dan data perusahaan yang telah dikemukakan pada bab sebelumnya, maka penulis akan mengevaluasi serta mengkaji permasalahan yang telah dirumuskan pada bab 1. Prosedur pengeluaran kas yang di pakai pada PT Jasa Raharja (Persero) Cabang Sumatera Selatan sudah cukup baik hanya saja banyaknya prosedur-prosedur yang harus dilewati serta pengajuan santunan harus disertakan dengan persyaratan-persyaratan yang telah ditentukan dan harus melakukan pengecekan BKK-Bukti Jurnal Transaksi pada ERP.

Pada PT jasa raharja (persero) prosedur pengeluaran kas pada pembayaran santunan melakukan verifikasi berkas klaim :

a. Bagian keuangan dan akuntansi menerima berkas klaim dari bagian klaim.

b. Bagian keuangan dan akuntansi melakukan verifikasi berkas klaim yakni dengan meneliti kelengkapan, keabsahan, dan perhitungan dalam berkas klaim.

c. Bagian keuangan dan akuntansi melakukan vasilidasi lembar disposisi pengawal berkas (LDPB) dalam DASI-JR pelayanan online sebagai bukti verifikasi berkas klaim sudah dilakukan.

d. Bagian keuangan dan akuntansi menyerahkan berkas klaim kepada kepala cabang.

Melakukan validasi LDPB :

a. Bagian administrasi menerima berkas klaim dari kasubag keuangan \& akuntansi keuangan

b. Bagian administrasi melakukan validasi LDPB dalam DASI-JR pelayanan online bagian administrasi menyerahkan berkas klaim kepada kasir

Pembayaran secara tunai, prosedurnya sebagai berikut :

a. Kasir menerima berkas klaim dari kabag administrasi

b. Kasir melakukan varifikasi atas kelengkapan validasi LDPB dalam DASI-JR pelayanan online.

c. Kasir mencetak LDPB dari DASI-JR pelayanan online

$>$ Pembayaran secara tunai, prosedurnya sebagai berikut :

a. Kasir mencetak BKK - Bukti Jurnal Transaksi dari ERP

b. Kasir mengambil kuitansi pelayanan dari berkas klaim

c. Kasir menyerahkan berkas kepada claimant beserta BKK-Bukti Jurnal Transaksi dan kuitansi pelayanan untuk ditanda tangani oleh claimant.

Mencatat BKK-Bukti Jurnal Transaksi Dalam Buku Pembantu

a. kasir mencatat BKK-Bukti Jurnal transaksi dalam buku pembantu pengendali kas (BPPK)

b. Kasir menyerahkan berkas klaim asli kepada bagian klaim berkas klaim.

c. Kasir menyerahkan BKK Bukti Jurnal Transaksi kepada kasubag keuangan dan akuntansi 
Mencetak LDPB

a. Kasir menerima berkas klaim dari bagian administrasi

b. Kasir melakukan varifikasi atas kelengkapan validasi LDPB dalam DASI-JR pelayanan online.

Pembayaran secara non tunai dengan menggunakan bilyet giro prosedur prosedurnya sebagai berikut :

a. kasir menyiapkan surat perintah transfer (SPT) dan BG

b. BG dan SPT ditandatangi oleh penjabat yang berwenang

c. Kasir mengcopy sebagai lampiran berkas klaim

d. Kasir mengantarkan BG dan SPT ke bank. Bank mengvasilidasi SPT

e. Kasir memberikan materai pada tindasan SPT sesuai ketentuan yang berlaku

Pembayaran secara non tunai dengan menggunakantoken prosedur sebagai berikut :

a. Kasir menyiapkan surat perintah transfer secara online (SPT online) dalam CMSuntuk diotoritas penjabat yang berwenang mengotarisasi pembayaran menggunakan token mengacu pada peraturan perusahaan yang berlaku

b. SPT online yang sudah diotorisasi akan dikirim secara otomatis ke bank

c. Kasir mencetak SPT online dari CMS

d. Kasir memberikan materai pada SPT online sesuai ketentuan yang berlaku

e. Kasir mencetak BKK-Bukti jurnal Transaksi dari ERP

f. Kasir menandatangani BKK-Bukti Jurnal Transaksi

g. Kasir mencatat BKK-Bukti Jurnal Transaksi dalam buku pembantu pengandalian bank (BPPB)

h. Kasir menyerahkan berkas klaim asli kepada bagian klaim

i. Kasir menyerahakan BKK-Bukti Jurnal Transaksi kepada bagian keuangan dan akuntansi

Melakukan Vasilidasi Bkk-Bukti Jurnal Transaksi

a. keuangan dan akuntansi menerima BKK-Bukti Jurnal Transaksi dari kasir.

b. keuangan dan akuntansimengecek dalamERP apakah jurnal yang tertera pada BKK-Bukti Jurnal Transaksi / BBK-Bukti Jurnal Transaksi sudah tepat

C. Apabila jurnal sudah tepat, keuangan dan akuntansi menandatangani BKKBukti Jurnal Transaksi/ BBK-Bukti Jurnal Transaksi dan melakukan validasi BBK-Bukti Jurnal Transaksi pada ERP

d. Apabila terjadi kesalahan keuangan dan akuntansimengembalikan BKKBukti Jurnal Transaksi/ BBK-Bukti Jurnal Transaksi kepada kasir untuk dilakukan pencetakan ulang BKK-Bukti Jurnal Transaksi/ BBK-Bukti Jurnal Transaksi

e. Kasir meminta bagian pelayanan untuk melakukan koreksi data dalam DASI-JR pelayanan online

f. Setelah data dikoreksi oleh bagian pelayanan kasir melakukan pencetakan ulang BKK-Bukti Jurnal Transaksi / BBK-Bukti Jurnal Transaksi. Kasir menandatangani BKK-Bukti Jurnal Transaksi/ BBK-Bukti Jurnal Transaksi yang baru terlebih dahulu 
g. keuangan dan akuntansi menyerahkan BKK-Bukti Jurnal Transaksi/ BBKBukti Jurnal Transaksi yang sudah ditandatangani kepada kasir untuk kepentingan pelaporan harian kantor cabang.

Berdasarkan teori flowchart pengeluaran kas yang di menurut Mulyadi $(17: 439)$

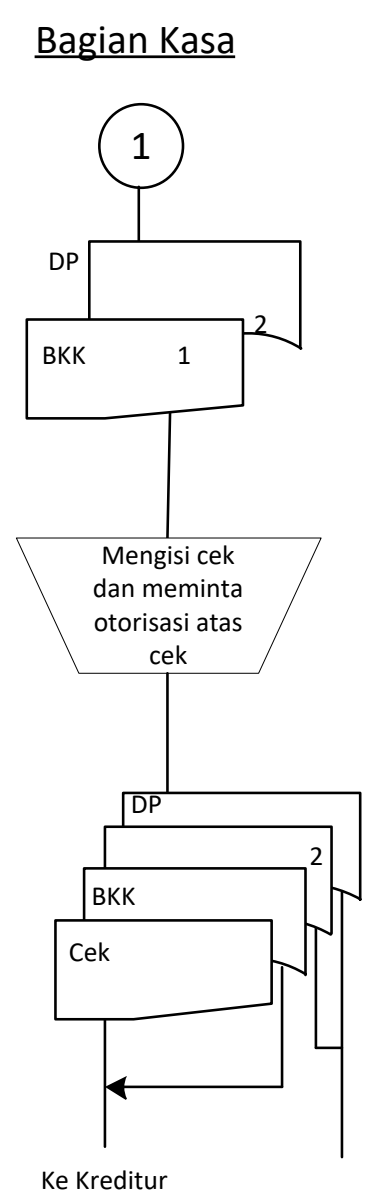

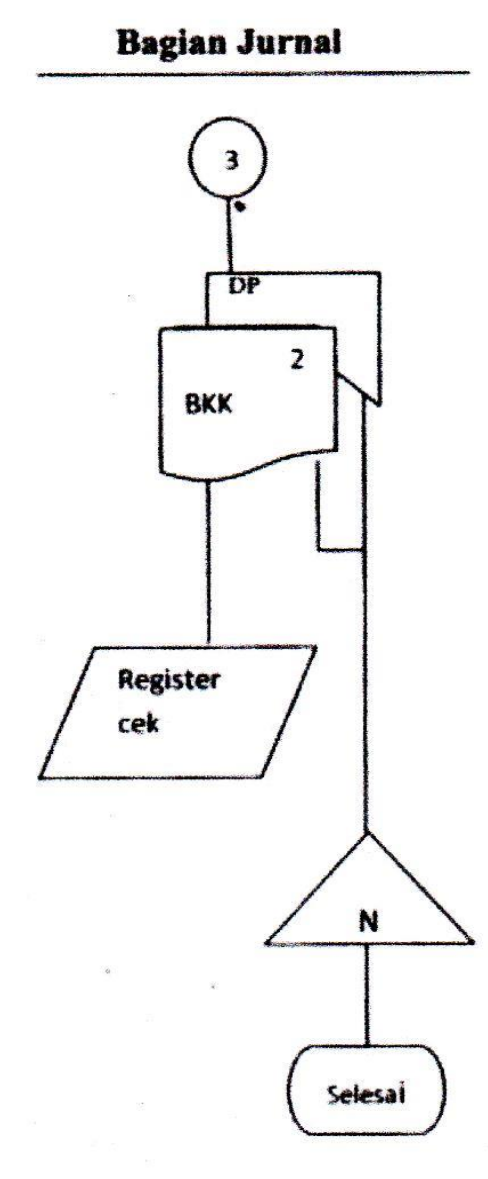

\section{Gambar 4.6 \\ Prosedur pengeluaran kas}

Menurut flowchat Mulyadi (2017:439) prosedur pengeluran kas ialah kasir menerima dokumen pendukung, kasir meminta cek atas nama dan dan meminta otorisasi atas cek daripejabat yang berwenang, kasir mengirim cek dengan dilampiri bukti kas keluar sebagai surat pemberitahuan kepada kreditur, pada bagian jurnal menerima bukti kas keluar beserta dokumen pendukung dari bagian kasir kemudian mencatat bukti kas keluar dan dokumen pendukung dalam register cek. Sedangkan pada PT Jasa Raharja (Persero) prosedur pengeluaran kas ialah, pada pembayaran secara online kasir melakukan otoritasi untuk meminta tanda tangan penjabat yang berwenang, pada pembayaran tunai kasir meyerahkan bukti kas keluar dan kwitansi pelayanan untuk di tanda tangani claimant, pada bagian keuangan dan akuntansi menerima BKK-Jurnal Kas Transaksi serta berkas dari kasir, bagian keuangan dan akuntansi megecek ERP apakah Jurnal yang tertera sudah tepat dengan ERP, apabila jurnal telah tepat bagian akuntansi menandatangani BKK- Bukti Jurnal 
Transaksi dan melakukan vasilidasi BKK-Jurnal Transaksi apabila terjadi kesalahan bagian akuntansi mengembalikan BKK-Jurnal Transaksi kepada kasir untuk dicetak ulang.

\section{1) Analisis Penyesuian Prosedur Pengeluaran Kas Menurut Akuntansi}

\section{a. Prosedur Pengeluaran Kas Menurut Akuntansi}

Menurut flowchat Mulyadi (2017:439) prosedur pengeluran kas ialah kasir menerima dokumen pendukung, kasir meminta cek atas nama dan dan meminta otorisasi atas cek daripejabat yang berwenang, kasir mengirim cek dengan dilampiri bukti kas keluar sebagai surat pemberitahuan kepada kreditur, pada bagian jurnal menerima bukti kas keluar beserta dokumen pendukung dari bagian kasir kemudian mencatat bukti kas keluar dan dokumen pendukung dalam register cek.

\section{b. Prosedur Pengeluaran Kas Menurut Perusahaan}

Pada PT Jasa Raharja (Persero) prosedur pengeluaran kas ialah, pada pembayaran secara online kasir melakukan otoritasi untuk meminta tanda tangan penjabat yang berwenang, pada pembayaran tunai kasir meyerahkan bukti kas keluar dan kwitansi pelayanan untuk di tanda tangani claimant, pada bagian keuangan dan akuntansi menerima BKK-Jurnal Kas Transaksi serta berkas dari kasir, pada bagian keuangan dan akuntansi megecek ERP apakah Jurnal yang tertera sudah tepat dengan ERP, apabila terjadi kesalahan bagian akuntansi mengembalikan BKK-Jurnal Transaksi kepada kasir untuk dicetak ulang, apabila jurnal telah tepat bagian akuntansi menandatangani BKK- Bukti Jurnal Transaksi dan melakukan vasilidasi BKK-Jurnal Transaksi setelah di tandatangani maka BKK tersebut akan d kembalikan pada kasir untuk dilakukan pencatatan pelaporan.

\section{2) Analisis Prosedur pengeluaran kas terhadap Pemabayaran Santunan}

Kemampuan suatu perusahaan PT Jasa Raharja (Persero) Cabang Sumatera Selatan menjadi tolak ukur baik atau tidaknya perusahaan asuransi tersebut. Dalam melaksakan kewajibannya membayar santunan PT Jasa Raharja (Persero) Cabang Sumatera Selatan sudah cukup baik akan tetapi masih banyak prosedur yang harus dilewati. Pengajuan santunan harus disertakan dengan kelengkapan berkas yang sesuai dengan persyaratanpersyaratan yang telah ditentukan dan apabila persyaratan-persyaratan tersebut belum lengkap maka permohonan pengajuan santunan belum bias diproses.

Menurut Febriani (2014:43) yang berjudul Analisis Sistem Dan Prosedur Pengeluaran Kas Terhadap Pembayaran Klaim Pada AJB Bumi Putra 1912 cabang Cinde Palembang.Penelitian ini menjelaskan sistem dan prosedur pengeluaran kas terhadap pembayaran klaim. Hasil penelitiannya adalah Prosedur pembayaran klaim yang dilakukan perusahaan sudah cukup baik, tetapi dalam pemorosesannya pembayaran klaim masih kurang efektif.Hal ini terjadi karena klaim baru dapat diproses apabila persyaratan atau berkas- 
berkas yang ada pada pemengang polis sudah lengkap secara keseluruhan. Hal ini biasanya akan memperlambat proses pembayaran klaim.

Menurut Nendra Saputra (2017:41)berjudul Prosedur Pengeluaran Kas(Pembayaran Klaim) Pada PT. Jiwasraya (Persero) Kantor cabang Palembang Kota menjelaskan tentang prosedur pengeluaran kas terhadap pembayaran klaim. Hasil penelitiannya adalah Prosedur pembayaran klaim yang dilakukan perusahaan sudah cukup baik, tetapi dalam pemerosesannya pembayaran klaim masih kurang efektif.hal ini terjadi karena klaim baru dapat diproses apabila pada persyaratan atau berkas-berkas yang ada pada pemegang polis sudah lengkap secara keseluruhan. hal ini biasanya akan memperlambat proses pembayaran klaim.

Berdasarkan penelitian diatas prosedur pengeluaran kas untuk pembayaran santunan pada PT Jasa Raharja sudah cukup baik namun proses pengeluaran kas pada bagian keuangannya masih melakukan pengecekan BKK-Bukti Jurnal Transaksi yang terkadang BKK-Bukti Jurnal Transaksi belum tepat dengan ERP perusahaan sehingga bagian kasir melakukan pencetakan ulang.

\section{J. KESIMPULAN DAN SARAN}

\section{1) Kesimpulan}

a. Berdasarkan hasil penelitian yang telah dilakukan pada prosedur pembayaran santunan sudah cukup baik akan tetapi masih banyak prosedur yang harus dilewati. Pengajuan santunan harus disertakan dengan kelengkapan berkas yang sesuai dengan persyaratan-persyaratan yang telah ditentukan dan apabila persyaratan-persyaratan tersebut belum lengkap maka permohonan pengajuan santunan belum bias diproses.

b. Berdasarkan hasil penelitian prosedur pengeluaran kas pada pembayaran santunan pada PT Jasa Raharja sudah cukup baik namun proses pengeluaran kas pada bagian keuangannya masih melakukan pengecekan BKK-Bukti Jurnal Transaksi yang terkadang BKK-Bukti Jurnal Transaksi belum tepat dengan ERP perusahaan sehingga bagian kasir melakukan pencetakan ulang.

\section{2) Saran}

a. Peneliti memberikan saran pada pembayaran santunan agar pembayaran santunan yang dilakukan oleh perusahaan tidak terlambat, sebaiknya perusahaan menyimpan arsip-arsip pemegang polis sebagai syarat pengambilan santunan.

b. Peneliti memberikan saran sebaiknyakasir melakukan pengecekan BKK-Bukti Jurnal Transaksi terlebih dahulu pada ERP denganbenardantelitisesuaidengan ERP PT Jasa Raharja (Persero) agar pada bagian akuntansi dan keuangan hanya tinggal menandatangani BKK-Bukti Jurnal Transaksi sehingga kasir tidak bekerja dua kali untuk melakukan pencetakan ulang bukti kas keluar tersebut 


\section{DAFTAR PUSTAKA}

Kasmir. 2013. Bank Dan Lembaga Keuangan Lainnya.penerbit rajawali pers. Jakarta

Krismiaji, 2010. Sistem Informasi Akuntansi. Yogyakarta: UPP AMP YKPN.

Latumaerissa. Julius R. 2011.Bank Dan Lembaga Keuangan Lainnya.penerbit selemba empat. jakarta selatan.

Mulyadi. 2017.Sistem Akuntansi.edisi ke empat. penerbit selemba empat. yogyakarta.

Purnomo.Hendri. 2015. Prosedur Simpan Pinjam Pada Koperasi Karyawan PRIMKOPAD Rindam II Palembang.

Samryn. 2011.Pengantar Akuntansi .penerbit rajawali pers. jakarta.

Saputra.Nendra. 2014. Analisis Rosedur Pengeluaran Kas (Pembayaran Klaim) Pada PT. Asuransi Jiwasraya kantor cabang palembang kota.

Sugiyono, 2013.Metode Penelitian Bisnis.penerbit Alfabeta. Bandung.

Undang- Undang Republik Indonesia No 33 dan 34 tentang Tahun 1964 Tentang Dana Pertanggungan Wajib Kecelakaan Penumpang

Yuliana, Tri. 2014. Analisa Prosedur Pembayaran Klaim Habis Kontrak Dan Meninggal Pada AJBPUTERA 1912 kantor cabang plaju. 